\title{
Multilateralism versus Regionalism in Eurasia: Theoretical Reasons of Choosing Sides for Kyrgyzstan
}

\author{
Zamirbek Manasov (Middle East Technical University, Turkey)
}

\begin{abstract}
This paper asks whether Kyrgyzstan should take part in the newly established Customs Union among Belarus, Kazakhstan and Russia or in the World Trade Organization (WTO). From the start of the foundation of the new Customs Union there have been deep discussions among the proponents and opponents of organization. This issue attracted extra attention and interest because the new Customs Union includes non-members of the World Trade Organization such as Russia, Belarus, and Kazakhstan. In Addition, the new Customs Union, unlike previous regional trade agreements, has formed a supranational body -the Custom Union Commission - which will decide on Common External Tariffs. Kyrgyzstan is already a member country of WTO and is going to join the new Customs Union. How will this membership work for Kyrgyzstan in short and long-term period? Will the new Customs Union be substitutive or complementary to the WTO in the development of international trade of Kyrgyzstan? Which side would be more beneficial for Kyrgyzstan: membership to a regional Customs Union or to a multilateral WTO? This paper hopes to answer these main questions. This paper will have five sections. Section one will provide a brief introduction. Section two will analyze the development of regionalism and multilateralism in the region. In section three, theoretical compatibility of regionalism and multilateralism will be discussed. Section four will determine what can be proposed for the current situation of Kyrgyzstan according to selected theoretical literature. Concluding remarks will be given in last section.
\end{abstract}

JEL Code: F13

\section{Introduction}

With the collapse of the Soviet Union in 1990, intra-trade among post-Soviet states suffered due to the breakdown in traditional market structures and a lack of alternative trade framework. Therefore, the concerned states immediately set the agenda to solve the Soviet-type economic interdependency among the republics and the infrastructure set in accordance with this model. The lack of experience in governance, both in the public and private sectors, further complicated the situation. The needed solutions were therefore more complex than expected. These countries must not only decide whether or not to cooperate and integrate and with whom, but also how deep should the cooperation be since there are political, social and economic costs. In this respect, within the short period of time, they established diplomatic relations with most countries of the world. They became members of the United Nations and other international organizations, such as the International Monetary Fund and the World Bank. They also signed hundreds of interstate treaties and trade agreements and entered into highly complex trade and economic relations with over 140 countries. However, during the entire independence period, trade relations in the post-Soviet area have also become more complicated. It seemed like the trade relations among these states have developed under the simultaneous influence of two directions: regionalism and multilateralism.

\section{Regionalism}

Post-Soviet States have undertaken to establish or re-establish different region-based organizations within the two decades after the independence. These organizations consist of either exclusively Former Soviet Union countries (Commonwealth of Independent States, Eurasian Economic Community, Central Asian Cooperation Organization), or also include other countries (Economic Cooperation Organization, Shanghai Cooperation Organization). The importance of these organizations for analysis is that they best represent the efforts of the Central Asian states to create a case for regionalism (Esengul, 2009).

The lack of effectiveness of all these organizations in terms of fostering trade and economic cooperation, which were urgently needed for every participating country, has been mentioned in many literatures. This paper does not aim to discuss the effectiveness or success, the cooperation potential, and the plans or their (non)implementation by these region-based organizations. However, as a part of this paper, it is necessary to show the impact of these organizations on regional trade rules and patterns.

In the early 1990s the Commonwealth of Independent States (CIS) countries adopted a Free Trade Agreement (FTA) with zero import tariffs for all goods originating from all the countries that signed up to it. This multilateral free trade arrangement was also reinforced by bilateral agreements between CIS countries (Jonson, 2004; 60). However, it is necessary to note that such bilateral free trade agreements allowed parties to introduce import duties on a limited number of commodities, either to protect sensitive domestic industries or as antidumping measures. 
Furthermore, several CIS members started to use temporary import bans against selected neighbors as a weapon in a variety of bilateral trade disputes or as an emergency measure, even if they have signed multilateral and bilateral trade agreements. For example, Russia and Ukraine have engaged in a number of bilateral disputes involving mutual bans of trade in certain commodities; Uzbekistan has cut off imports from the Kyrgyz Republic in retaliation for non delivery of electricity; and Kazakhstan has imposed prohibitive duties on trade with neighboring countries to deal with its balance of payments problems (Broadman 2005; 129). In other words using trade as a weapon in settling disputes has become an ordinary issue that decreased the workability of the CIS.

Relating or depending on their new independent economic, political and social policies, the leaders of some post-Soviet republics started to organize new regionalism processes within the CIS. These sort of new organizations were the result of internal policies of the initiating countries. For example, Kazakhstan President Nazarbayev put forward the idea of creating a new integration structure on the basis of the CIS, the Eurasian Union (Kulchik, 1996; 44). Nazarbeyev's Eurasian Union aimed at introducing common borders and creating super national currency. According to Nazarbayev, this would not mean the destruction of the CIS. On the contrary, the Eurasian Union (EurasEC) would act as a strong nucleus for region.

In 2000, the countries of the Customs Union (EurasEC) concluded an agreement on a Common Customs Tariff (Gürer, 2005). This agreement provides a five-year period (which can be further expanded) for the formation of a Common Customs Tariff with a special permission for Kyrgyzstan and Tajikistan to establish their own time schedules for the adoption of the tariff. The EurasEC strategy focused on a customs union and an eventual single currency for the region (Gleason, 2001). It emphasized economy-based issues more than the CIS and was designed to sponsor cooperation in five broad categories: free trade, customs; common market or products; services and labor; and a currency or monetary union. However, in terms of efficiency it was not different from the CIS.

The Central Asian Cooperation Organization (CACO) (and its predecessor, the Central Asian Economic Community) provides a forum for discussing and developing coordinated policy with regards to water and energy exchange issues that would require regional participation. Central Asian leaders have attempted to distinguish $\mathrm{CACO}$ from its predecessor by emphasizing improved effectiveness. Agreements and multilateral treaties were signed under CACO, sort of following the EU model. Examples include the coordination of tax collection methodology, indirect taxes, simplification and harmonization of customs rules (EurasEC), information exchange in different areas (CIS, EurasEC, CACO), and the rather unsuccessful attempt to establish the Central Asian Cooperation and Development Bank. However, enforceable agreements have been achieved so far mainly on a bilateral basis. Very few other practical results from regional organization activities have been achieved. According to President Karimov of Uzbekistan, the CACO had in many ways repeated the experience of the CIS. More than 250 CACO decisions were adopted but were not implemented. Many of the CACO's documents have proven to be as totally redundant as those of the CIS, Karimov concluded (Karasar, 2009). For Uzbekistan, CACO was considered as a tool for control over the region by a potential hegemonic power (Swanstrom, 2004; 44). In addition, as was mentioned by Esengul (2009; 128), fear of Russian neo-imperialism was considered as one of the sources of ineffectiveness of the CIS. Being sub-regional structures of the CIS, the $\mathrm{CACO}$ and EurasEC faced the same problems, fears and expectations.

In fact, there has not been any regional trade regulation with practical implications that has ever fully entered into force; only framework documents and declarations have been adopted in all regional organizations. Of course, trade and economic cooperation in the region did take place, but it was regulated by bilateral agreements or by the authority of leaders. In other words, besides bilateral agreements, the leaders of Central Asian states played a key role in shaping the emerging polities and institutions. Similarly, Moscow will play leading role in the new Customs Union. In all these states, a small group of authoritarian ruling elites has played the key role in shaping the emerging political and economic orders. These ruling elites have been unwilling to create regional organizations which would adversely affect their newly won sovereignty (Bohr, 2004; 501). It is difficult to say that the concept of regionalism can be used in all sense in the region (Chinara Esengul 2009).

\section{Multilateralism}

In pursuit of multilateralism, all these countries in question have applied for GATT and its successor, the WTO. For example, Russia and Belarus applied in 1993 and Kazakhstan applied in 1996. WTO accession never received strong support from President Boris Yeltsin. But soon after President Vladimir Putin came to office, Russia made WTO accession a priority. He created the massive Ministry of Economic Development and Trade and appointed a reformer, German Gref, as its head (Tarr, 2007). The Working Party on the accession of Belarus to the WTO was established on 27 October 1993 and held its first meeting in June 1997. Bilateral market access negotiations are ongoing on the basis of revised offers on goods and services. A revised Factual Summary of Points Raised was prepared by the Secretariat in June 2007. Comparing to other post-Soviet states accession process, Belarus has moved slowly. 
Kazakhstan's WTO Working Party was established on 6 February 1996. Bilateral market access negotiations are ongoing. The latest revision of the draft Report of the Working Party was circulated in June 2008. The Working Party held its tenth meeting in July 2008 (Khatibi, 2008). Among the other countries in the group, Kazakhstan has a relatively more developed market-oriented economy, but since the mid-1990s, its elite have been cautious about ceding discretionary economic power. This is reflected in the difficulties of the WTO negotiations regarding the administration of border controls by customs, quarantine, veterinary and other agencies (Pomfret, 2007; 40).

The WTO is the last major international organization of which Russia is not a member. More than 95 percent of world trade is carried out by the 153 WTO members, and Belarus, Kazakhstan and Russia remain outside of the WTO. They are still in the negotiation process. A prospective country has to go through a long application process that takes six years on average to complete, but these countries have been trying for seventeen years, which is much longer than any other applicant. This seems to buttress the notion that it is better for big countries to enter in most international negotiations, but when entering the WTO, the opposite is true. The bigger a trading partner country is, the more the other countries will be concerned about the effects of foreign trade will have on them. Every applicant must make a bilateral agreement on market access with every member who cares to make such a claim. Usually, 10-20 countries would be interested. For Russia, more than 60 member countries have demanded a bilateral protocol on market access (Aslund, 2010). Moreover, because the WTO decides on everything by consensus, each individual member can veto the entry of a new applicant. Russian officials are immensely irritated to see discrimination against their country because of its large size and they claim that it is inappropriate for Russia to be treated in such a way.

The main reason for Russia's slow approach to the WTO was that Russia's political leaders ignored the importance of the organization. Additionally, under the leadership of Putin in 2006, Russia's new policy of import substitution, extensive state intervention, industrial policy, and protectionism were reasons why Russia postponed joining the WTO. Russia undertook multiple protectionist measures in the following years. In May, 2008, when Medvedev took office, there was new reason to be optimistic about Russia's accession to the WTO. The new president repeatedly voiced his approval of the WTO in virtually all his major speeches, while Putin had ignored it during his last term as a president. However, in June 2009, Putin announced that Belarus, Kazakhstan, and Russia were abandoning their individual talks to join the WTO. Instead, they would enter as a single Customs Union. Putin's explanation was that the Customs Union was more important and could no longer be delayed for WTO accession (Aslund, 2010; 59-60). The end result however, was that Russia's almost complete accession to the WTO was jeopardized since after 16 years of negotiations, Russia was nearly ready to join the WTO.

Putin's novel proposal was the first application in the WTO history where countries wanted to access to the WTO as a group. No country has ever entered WTO collectively, which is not legally possible. Reacting to Putin's proposal, the General Secretary of the WTO declared that a Customs Union could not join the WTO. The Russian officials involved in the WTO negotiations then revised the meaning of its Customs Union joining the WTO to mean that the three countries will coordinate their accession to the WTO. In Kazakhstan, there is a common belief that, because of the close trade links with the Russian Federation, Kazakhstan's WTO accession should be coordinated with that of the Russian Federation. Yet, any coordination will necessarily slow down Russia, because Kazakhstan has not concluded its major bilateral protocols with the EU or the United States. Belarus on the other hand is still at an early stage of negotiations (Aslund, 2010; 60-62).

It would seem then that by declaring the intent to accede as a Custom Union, Putin simply delayed Russia's accession to the WTO for the foreseeable future. The reason is that Russia has less need for the WTO as compared to a manufacturing country like China. A series of World Bank and Russian studies has estimated that Russia can gain 0.5-1 percentage points in higher economic growth for a half decade if it joins the WTO. In other words, as was analyzed by Aslund (2010), rather than being a matter of trade policy, Russia's WTO accession has become political instrument of leaders in Moscow since there is little reason beyond political symbolism to synchronize accession dates. But there are good reasons for not delaying accession once substantive negotiations are complete.

In contrast to other Central Asian countries and Russia, Kyrgyzstan has pursued a two track policy of simultaneous regional and multilateral trade liberalization. It has become member of all the above-mentioned regional Organizations. As for the multilateral level, Kyrgyzstan began its accession process to the WTO in February 1996 and became a WTO member on 20 December 1998 (Rahmanova, 2000). Kyrgyz Republic remains the only WTO member among its Central Asian neighbors.

In order to boost economic growth, Kyrgyzstan has implemented a large-scale program aimed at political and macro-economic stabilization and structural reforms. The Government of Kyrgyzstan considered the complete integration of the country into the world trading system as a key to the long-term success of economic reforms and development. Kyrgyzstan recognized the necessity and importance of foreign investment since the country was without any significant industrial sector. In this context, Kyrgyzstan looked forward to have access to a great number of suppliers on the most favorable terms. Access to new foreign markets was indispensable for both 
balance of payment stabilization and for attracting foreign and domestic investors to industries. The first steps towards this goal were made in 1995 when experts of the relevant ministries and organizations of the country were sent to participate in the training seminars of the WTO (Quigley, 2004). In turn, Kyrgyzstan would access to major export markets, cheaper imports and the WTO's trade dispute settlement mechanism.

The Kyrgyz WTO experience indicates the importance of coherence between trade policy and domestic policy reform. Without domestic policy reform, WTO accession would be difficult. Kyrgyzstan would have benefited from its neighbors' concurrent accession. However, the lack of willingness on the part of the other Central Asian countries' and Russia's postponement to complete its WTO accession negotiations created contemporary disadvantages to Kyrgyzstan.

The Economic and fiscal costs of the WTO Membership are not negligible. Membership requires fairly large investments into the modernization and harmonization of various institutions directly involved in the conduct of foreign trade and investment (Drabek and Baccheta, 2010; 130). Accession is subject to a complex negotiation process, which is costly and which involves demands from existing member countries that the applicant countries do not necessarily consider to be in their own immediate interest. Accession commitments relate to market access, as well as policy rules not directly related to trade. Perhaps inevitably, bilateral or regional arrangements may often seem more attractive than WTO membership for some countries. As mentioned by Felbermayr and Kohler (2010), there is a "price" for WTO membership. Although the price is negotiable, the negotiating process is somewhat biased in favor of the existing members. Moreover, there is evidence that the price has risen through time (Evenett and Primo Braga, 2010). But, if countries are willing to pay this "price", so there must be some benefit from it.

What is important to point here is that the cost of membership for Kyrgyzstan is high and might not be negligible. In the studies of Drabek and Woo (2010) these costs are divided into separate groups: costs of accession, costs of implementation, costs of lost government revenues, and reduced scope for countries to conduct independent national policies. As indicated in their work, it is seems that it is not easy to switchover from central planning to market-based policy instruments. It might painful, but it is also highly valuable. Since joining the WTO strengthened the capacity of its market-based institutions and those specifically trade related, such as the financial sector, customs and trade facilitation, Kyrgyzstan is now better able to enjoy the benefits and meet the responsibilities of participation in multilateral trading system (Michalopoulos, 1999).

The Kyrgyzstan's experience indicates that WTO membership does not guarantee the provision of immediate benefits. It supports, but does not guarantee the expansion of export, fast industrialization, and development or the high levels of economic growth and unconditional growth of direct investments. The membership of countries in the WTO will allow resolving trade disputes between states based on WTO DSU (Dispute Settlement Understanding) rules and procedures. In view of these, therefore, it is important for Kyrgyzstan to promote the accession process of its neighbouring and main trading country-partners in the WTO, while using the advantage of its membership for providing market access for its goods.

\section{Regionalism versus Multilateralism in the Literature}

Many scholars cite the large number of Regional Trade Agreements (RTAs) notified to the WTO as evidence of the growth and significance of regionalism. From this perspective, because the number of RTAs notified to the WTO reached an all time high in early 2000s, regionalism appears more prevalent than ever. The main problem with using counts of RTAs as measures of the increasing importance of regionalism is that, while some agreements are important, many RTAs are inconsequential (Pomfret, 2006). For example, political and security considerations have been the main concern in the formation of all kinds of regional agreements, especially in the post-Soviet area.

There is another reason why non-member countries prefer Custom Union or RTAs rather than WTO. Free Trade Agreement (FTA) negotiations proceed more rapidly than WTO accessions and are completed more quickly. The average time for completing an FTA negotiation from the beginning of the negotiation to final entry into force is about 3 years. The average time for completing the task of a WTO working party is 6.9 years. Moreover, changes in economic conditions are much more in WTO accession than in an FTA negotiation. The process of FTA negotiations is simpler, while there may be a dozen or more members in a WTO accession party, each one representing separate agendas that may need bilateral and multilateral agreement (Ferrantino, 2010;143). A Customs Union among non-members might be a rescue vehicle in the short term. But in long term it is difficult to say if this same vehicle would be of help since there is an ongoing process among member countries of WTO to form or shape future multilateral trade rules and disciplines. There is no clear evidence of RTAs having superiority over WTO membership.

It should be noted that despite the fact that regionalism seems to function as a substitute, as Heydon mentioned, regional agreements can be a complement to the multilateral trading system, but they can never be a complete substitute for it (Heydon, 2008: 248). Regional agreements may in certain areas advance more quickly than is possible multilaterally, but they can never substitute for multilateral rulemaking. The issue of regionalism 
vs. multilateralism has generated a vast debate on whether the immediate consequences of regionalism for the economic welfare of the integrating partners encourage or discourage evolution towards a freer global trade. However, most analysts, including the WTO Secretariat, have concluded that on the whole, regional agreements have made a positive contribution to the liberalization of world trade.

Bhagwati (1999) expresses strong concerns about the negative effects of growing regionalism and worries that RTAs divert attention from the multilateral trading system. Bhagwati, in particular, stresses the benefits of free trade and rejects arguments about the need for an alternative to the GATT (WTO) for countries which wish to liberalize faster, for regionalism as a supplement to GATT (WTO), or for regionalism to accelerate the GATT processes.

Bagwell and Staiger (1999) questioned whether RTAs are "building blocks" or "stumbling blocks" for multilateral trade. They outlined a framework of effects with which to better understand the possible impact of regional agreements on multilateral trade. According to their analytical framework of effects, there are effects, under which regional agreements complement multilateral trade, and effects also exist under which regional agreements undermine the multilateralism. They concluded that RTAs are the building blocks for multilarelism. But when multilateralism system is working poorly, RTAs can have undesirable effects on multilateralism.

It is desirable then to analyze RTAs within the framework of WTO system. However, examination of specific RTAs within the framework of WTO has been troubled by disagreement about the interpretation of certain elements of the rules relating to RTAs as well as by certain procedural aspects. To solve this problem on the procedural side, the General Council of WTO replaced the previous system of separate working parties with the establishment of the Committee of Regional Trade Agreements (CRTA) in Febrary 1996 (Crawford and Laird, $2000 ; 5)$. The mandate of the CRTA is to carry out the examination of agreements referred to it by the Council for Trade in Services (agreements under Article V of the GATT) and the Committee on Trade and Development (agreements between developing countries). The CRTA is also charged to make recommendations on the reporting requirements for each type of agreement and to develop procedures to facilitate and improve the examination process. However, as analyzed in detail by Crawford and Laird (2000), in practice, the CRTA has not been able to resolve many of the systemic issues in the WTO. According to them, this certainly does the system little credit, but it is also a consequence of fundamental consensus process of the WTO.

\section{Theoretical Reasons of Choosing Side}

This section asks whether Kyrgyzstan should join the new Customs Union or stay in the WTO. During the WTO membership Kyrgyzstan initiated many reforms leading to the modernization of trade policy and entrance to the world market. RTAs have generally proved to be poorly suited to promoting trade liberalization and have created restrictions rather than supports. In addition, RTAs in general have become a vehicle for promoting political views or policies rather than a vehicle for development of regional trade. Therefore, in this section we will mainly discuss the reasons why Kyrgyzstan should stay within the WTO. As this paper seeks to analyze just the theoretical side of developments about RTAs and the WTO in the Kyrgyzstan, the reasons that will be put forward here will reflect essentially the theoretical analysis from relevant literature.

In the literature, (Drabek and Baccheta,2010) the reasons can be grouped under two categories: theoretical arguments and practical considerations. In this section the theoretical side of reasoning will be emphasized since, the practical side would need more empirical studies and field research in the region. In addition there are no common points among those states about the practical benefits of multilateralism.

The attractiveness of the WTO has several dimensions. One of the attractive sides of WTO is that governments are able to obtain an improved access to markets for their exports. By staying outside the WTO, the countries' trade partners would be in a position to apply discriminatory tariffs against non-members. In addition, non-member countries would have to negotiate border measures with their partners bilaterally or regionally. The WTO is, therefore, particularly important for small countries that have a limited power to exploit their size to improve their terms of trade.

Another reason why countries may be interested in joining the WTO is the beneficial effect of the WTO lending credibility to government policies. Governments often face a credibility gap in trying to convince foreign and domestic investors and the rest of the business community about their commitments to particular policies. Unlike the Customs Union policy reforms, policy reforms of the WTO are more credible because of the strategic interaction among the members and between the government and the private sector that makes the agreement interactive (Drabek and Baccheta, 2010; 98).

In addition, as Pomfret (2010) argued, the Regional Trade Agreements, including the Customs Union, have proved to be poorly suited to promoting trade liberalization and have created rather than resolved trade disputes. He tried to answer why countries are keen to join the WTO and why are they often disappointed after accession? According to him, applicants often have false expectation of benefits while new members find that they have underestimated the costs of accession, which make many countries disappointed. The benefits of WTO membership are real, but the most important ones are indirect and general. To a significant degree, the benefits 
from a rules-based international trading system are network benefits (Pomfret, 2010; 184). Being part of the common trading system rules and network benefits of WTO is preferable to the regional Customs Union.

Another point that is generally underestimated is the potential benefits from the WTO dispute settlement mechanism. During the GATT era (1947-1994) the system was biased in favor of the major trading nations, both in coverage trade liberalization and in effective recourse against countries breaking GATT rules. For example, multilateral trade negotiations were dominated by the U.S., EEC, Japan, and Canada during the GATT period. However, after the WTO establishment, a Dispute Settlement Mechanism was formed that has provided much greater involvement of middle and low income countries either individually or as the G20. In other words, in terms of negotiation process, WTO members have equal rights. There are few effective vehicles to resolve international trading disputes outside commercial arbitration, and those that exist can disfavor small trading nations against big ones. The WTO Dispute Settlement Mechanism provides a uniquely fair, accessible, and effective opportunity to each WTO member-irrespective of its size and level of income (Davey, 2010).

A set of norms and institutions that support the liberalization of markets, increase transparency and promote the rule of law, and that tighten the enforcement and the evolution of an independent judicial system are other beneficial effects of WTO membership on domestic policies and institutions. The role of WTO in this process is to facilitate the introduction of effective reforms not only by reinforcing the credibility of the government's trade policies but also by helping introduce polices that are based on best practices and policies that must be harmonized. The WTO is also considered to play an important and positive role in the development of predictability, security and transparency of market access. This should help to reduce incentives for corruption by providing countries with powerful institutional checks and balances in the international economic sphere. According to Drabek (2010), theory and evidence suggest that openness reduces corruption. Increased transparency and market-based institutions should further reduce rent-seeking behavior and corruption. The adherence to internationally acceptable rules governing international trade and foreign direct investment imposes stricter disciplines on governments and indirectly on firms. In other words, as summarized by Pomfret (2010), WTO accession deserves greater credit as a policy anchor.

As shown above, WTO membership is commonly regarded as a key vehicle to integrate less developed countries into the world trading system and thus to enhance their growth and development perspectives. Did the WTO deliver on this account? This question might have many dimensions and there is no easy answer. According to literature, the WTO should at least have had trade-promoting influence. However, empirical studies show that WTO is not perfect for promoting international trade. For example, the widely recognized study of Rose establishes that, "literature currently do not have strong empirical evidence that GATT/WTO has systematically played a strong role in encouraging trade" (Felmermayr and Kohler, 2010; 218). In other words, this paper argues that the WTO may not be the unique instrument for the promotion and development of trade among nations, but it is more qualified in the forming trade rules than other forms of RTAs.

\section{Conclusion}

This paper asks whether Kyrgyzstan should take part in the newly established Customs Union among Belarus, Kazakhstan and Russia or in the World Trade Organization. According to the analysis from theoretical literature it is concluded that Kyrgyzstan needs to say in the WTO. Joining to the new Customs Union is the short term solution to cope with the current situation in Kyrgyzstan as experienced during the past two decades. Past experiences show that FTAs among those states or trade related organizations in the region did not work properly. FTAs tend to keep contemporary policy rather than to solve the long term problems of international trade. In addition, the main member of the new Customs Union, Russia, is almost finished with its negotiation process to enter the WTO. It seems that by declaring the intent to accede as a Custom Union, Russia just delayed its accession to the WTO for the foreseeable future. There is little reason beyond political symbolism to synchronize accession dates among Russia, Kazakhstan and Belarus. Moreover, the new Customs Union could not be substituted for the WTO according to what have been discussed in the literature. This does not mean that the WTO system is perfect. Admittedly, there are lacking aspects of the WTO as in specifying the rules of the game in the dispute settlement mechanism. But it is far better than a world trading system without the rule of law. It is especially beneficial for developing countries, which may otherwise be subject to undesirable actions by larger trading countries. When we consider the contributions of the Customs Union and WTO to the development of international trade, the WTO membership is undeniably not only for Kyrgyzstan but also other countries.

\section{References}

- Aslund, Anders., 2010, “Why Doesn't Russia Join the WTO?”, Center for Strategic and International Studies, The Washington Quarterly, No 33:2 pp. 49-63

- Bagwell, Kyle, and Robert W. Staiger,1999, Regionalism and Multilateral Tariff Cooperation, in International Trade Policy and the Pacific Rim, ed.by John Piggott and Alan Woodland, New York: St. Martin's Press.

- Bhagwati, Jagdish, and Arvind Panagariya, 1999, Preferential Trading Areas and Multilateralism: Strangers, Friends or 
Foes?," in Regionalism in Trade Policy: Essays on Preferential Trading, ed. by Arvind Panagariya, River Edge, N.J. and London: World Scientific.

- Bohr, Annette., 2004, "Regionalism in Central Asia: New Geopolitics, Old Regional Order", International Affairs, Volume 80, Issue 3, pages 485-502.

- Broadman, H, G., 2005, From Disintegration to Reintegration, Eastern Europe and the Former Soviet Union in International Trade, The International Bank for Reconstruction and Development and The World Bank, Washington DC 20433.

- Crawford, Jo-Ann., Laird, Sam., 2000, "Regional Trade Agreements and the WTO”, Centre for Research in Economic Development and International Trade, University of Nottingham, No. 00/3.

- Davey, W. J., 2010, The WTO Dispute Settlement System: How Have Developing Countries Fared? in Is the World Trade Organization Attractive Enough for Emerging Economies? Critical Essays on the Multilateral Trading System, ed. by Zdenek Drabek. Palgrave Macmilan.

- $\quad$ Drabek, Z., Bacchetta, M., 2010, Effects of WTO Accession on Policymaking in Sovereign States: Lessons from Transition Countries, in Is the World Trade Organization Attractive Enough for Emerging Economies? Critical Essays on the Multilateral Trading System, ed. by Zdenek Drabek. Palgrave Macmilan.

- $\quad$ Drabek, Z., Woo, W. T., 2010, Who Should Join the WTO and Why?: A Cost-benefit Analysis of WTO Membership, in Is the World Trade Organization Attractive Enough for Emerging Economies? Critical Essays on the Multilateral Trading System, ed. by Zdenek Drabek. Palgrave Macmilan.

- Esengul, Chinara., 2009, The Politics of Regionalism in Central Asian, Ministry of Education and Science of the Kyrgyz Republic, The Jusup Balasagyn Kyrgyz National University, Institute for Integration of International Educational Programs.

- $\quad$ Evennet, S, J., Braga, C. A. Primo., 2005, "WTO Accession: Lessons From Experience”, World Bank Trade Note, No 22.

- Felbermayr, G., Kohler, W., 2010, Does WTO Membership Make a Difference at the Extensive Margin of World Trade, in Is the World Trade Organization Attractive Enough for Emerging Economies? Critical Essays on the Multilateral Trading System, ed. by Zdenek Drabek. Palgrave Macmilan.

- Ferrantino, M.J., 2010, Policy Anchors: Do Free Trade Agreements and WTO Accessions Serve as Vehicles for Developing- country Policy Reforn?, in Is the World Trade Organization Attractive Enough for Emerging Economies? Critical Essays on the Multilateral Trading System, ed. by Zdenek Drabek. Palgrave Macmilan

- Gürer, Heidemaria., 2005, Forms of Regional Cooperation in Central Asia, in Facing the Terrorist Challenge -Central Asia's Role in Regional and International Co-operation, Study Groups Regional Stability in Central Asia Security Sector Reform, Vienna and Geneva.

- Gleason, Gregory, 2001, "Inter-State Cooperation in Central Asia from the CIS to the Shanghai Forum", Europe-Asia Studies, Vol. 53, No. 7, pp. 1077-1095

- Heydon, Ken., 2008, Asymmetric Integration: The Role of Regionalism, in Developing Countries and the WTO: Policy Approaches, ed. by Gary P. Sampson and W. Bradnee Chambers, United Nation University Press, pp. 229-251.

- Jonson, L., 2004, Vladimir Putin and Central Asia, the Shaping of Russian Foreign Policy, St Martins Press, New York.

- Quigley, John., 2004, Kyrgyzstan's accession to the WTO, EurAsia Bulletin Volume 8 Number $1 \& 2$ Jan-February.

- Karasar, H.A., Kuşkumbayev, K., 2009, Türkistan bütünleşmesi : merkezi Asya'da birlik arayışları, Otuken Press, Istanbul.

- Khatibi, Arastou., 2008, “Kazakhstan's Accession to the WTO: A Quantitive Assessment”, ECIPE Working Paper, no. 02

- $\quad$ Kulchik, Y., Fadin, A., and Sergeev, V., 1999, Central Asia after the Empire, Pluto Press, London and Chicago.

- Michalopoulos, Constantine., 1999, "The Integration of Transition Economies into the World Trading System”, Fifth Dubrovnik Conference on Transition Economies, Dubrovnik Croatia, June 23-25.

- $\quad$ Pomfret, R., 2007, Lessons from Kyrgyzstan's WTO Experience for Kazakhstan, Tajikistan and Uzbekistan, AsiaPacific Trade and Investment Review Vol. 3, No. 2.

- $\quad$ Pomfret, R., 2010, Regional Trading Aggrements and WTO membership: Substitutes or Complements, Is the World Trade Organization Attractive Enough for Emerging Economies? Critical Essays on the Multilateral Trading System, ed. by Zdenek Drabek. Palgrave Macmilan.

- $\quad$ Rahmanova, Anarkan., 2000 , Kyrgyzstan, Country papers on accession to the WTO, Ministry of External Trade and Industry, Kyrgyzstan.

- Tarr, D., 2007, "Russian Accession to the WTO: An Assessment," Eurasian Geography and Economics, Vol. 48, No. 3, May-June, pp. 306-319. 